\title{
A gastropod scavenger serving as paratenic host for larval helminth communities in shore crabs
}

Latham, A D M; Fredensborg, Brian Lund; McFarland, L H; Poulin, R

Published in:

Journal of Parasitology

DOI:

10.1645/GE-73R

Publication date:

2003

Citation for published version (APA):

Latham, A. D. M., Fredensborg, B. L., McFarland, L. H., \& Poulin, R. (2003). A gastropod scavenger serving as paratenic host for larval helminth communities in shore crabs. Journal of Parasitology, 89(4), 862-4.

https://doi.org/10.1645/GE-73R 


\title{
Neurotoxicity and Immunotoxicity Assessment in CBA/J Mice with Chronic Toxoplasma gondii Infection and Multiple Oral Exposures to Methylmercury
}

\author{
Marquea D. King*, David S. Lindsay, S. Holladay, and M. Ehrich, Department of Biomedical Sciences and Pathobiology, Virginia-Maryland \\ Regional College of Veterinary Medicine, Virginia Tech, Blacksburg, Virginia 24061; *Present address: National Center for Environmental \\ Assessment, U.S. Environmental Protection Agency, 1200 Pennsylvania Avenue, NW, MC 8623-D, Washington, D.C. 20460. e-mail: \\ lindsayd@vt.edu
}

ABSTRACT: The present study was conducted to determine the effect of multiple low doses of methylmercury $(\mathrm{MeHg})$ on the course of a chronic Toxoplasma gondii infection. Four groups of 6-wk-old female CBA/J mice either were fed $25 T$. gondii tissue cysts of the ME-49 strain or were vehicle control. Six weeks later, half of each group was orally gavaged with $8-\mathrm{mg} / \mathrm{kg}$ body weight doses of $\mathrm{MeHg}$ on days 0 , $2,4,7,10$, and 13, totaling 4 experimental groups. Mice were killed on day 17 or 18 after $\mathrm{MeHg}$ exposure. Flow cytometric analysis of lymphocyte subpopulations in the thymus demonstrated a significant increase in the percentage of $\mathrm{CD}^{-} \mathrm{CD}^{+} \mathrm{T}$-cells in mice exposed to $\mathrm{MeHg}$ with a concurrent $T$. gondii infection. Groups of mice exposed to $\mathrm{MeHg}$ showed a decrease in total thymic cellularity and cellularity of all T-cell subpopulations when compared with control mice, but viability of these cells was unaffected. Splenic cell viability was decreased in mice exposed to $\mathrm{MeHg}$, but alterations in T-cell subpopulations were not noted. These data indicate that multiple low doses of $\mathrm{MeHg}$ may not exacerbate chronic toxoplasmosis, but MeHg-induced effects on the immune system were evident.

Toxoplasma gondii is a protozoan parasite that can cause a life-threatening disease in congenitally infected infants and immunocompromised patients. People become infected with $T$. gondii by ingesting tissue cysts in undercooked meat or by ingesting oocysts excreted by cats. Toxoplasmosis in the central nervous system is a common cause of brain lesions in acquired immune deficiency syndrome patients. In some patients suffering from toxoplasmic encephalitis, the infection may be lethal (Daubener et al., 1997; Belanger et al., 1999). Toxoplasmic encephalitis is caused by the reactivation of latent tissue cysts of $T$. gondii. Once reactivated, the tachyzoites released from tissue cysts destroy nervous tissue and cause progressive meningoencephalitis (Gazzinelli et al., 1993).

Neurotoxicants also damage nervous tissue, but few studies examining interactions of $T$. gondii and neurotoxicants have appeared in the literature (King et al., 2003). For example, methylmercury $(\mathrm{MeHg})$ is a well-documented neurotoxicant that accumulates in the brain and causes severe mental and visual dysfunction, including chronic encephalopathy (U.S. Department of Health and Human Services, 1994; Schaumburg et al., 2000). Contaminated fish, grains, and seeds are a common source of human exposure to $\mathrm{MeHg}$. In addition to being neurotoxic, MeHg is also immunotoxic (Moszczynski, 1997), enhancing the probability of interaction with $T$. gondii. Therefore, it was hypothesized that $\mathrm{MeHg}$ accumulation could worsen a chronic $T$. gondii infection. In the present study, multiple dosing with $\mathrm{MeHg}$ was used to provide longer exposure to this neurotoxicant than a single dose, with the potential of increasing time for a deleterious $\mathrm{MeHg}-T$. gondii interaction.

Six-week-old female CBA/J mice obtained from Jackson Laboratories (Wilmington, Massachusetts) were used for experimental $T$. gondii infection and $\mathrm{MeHg}$ exposure $(\mathrm{n}=10$ per group). These mice were used for this study because they are resistant to acute infection but are prone to develop encephalitis during a chronic infection (Suresh et al., 1991). Toxoplasma gondii dosing was as described previously (King et al., 2003). Methylmercury II chloride (Alfa Aesar, Ward Hill, Massachusetts) was dissolved in dimethyl sulfoxide (DMSO) at room temperature and diluted with phosphate buffered saline (PBS; 1:100). Oral doses of $8 \mathrm{mg} / \mathrm{kg}$ body weight were given to each mouse on days 0,2 , $4,7,10$, and 13. Vehicle controls received a DMSO-PBS suspension. The 4 experimental groups of mice used were vehicle control, $T$. gondii, $\mathrm{MeHg}$, and T. gondii-MeHg. The 8-mg/kg dosage chosen for multiple oral exposure was based on a dose response study done previously in our laboratory.

After killing by $\mathrm{CO}_{2}$ inhalation 17-18 days after the initial $\mathrm{MeHg}$ exposure, the spleen, thymus, brain, and left kidney were removed. The left half of the brain and the left kidney were used for analysis of $\mathrm{MeHg}$ concentration using a cold vapor accessory method of atomic absorption. The thymus and spleen were immediately weighed and then prepared for detection of cell surface markers using flow cytometry (King et al., 2003). These data are presented as mean \pm SE of the percentage of cells that express the surface marker of $\mathrm{CD}^{+}, \mathrm{CD}^{-} \mathrm{CD} 8^{-}$(DN, double negative), $\mathrm{CD}_{4}{ }^{+} \mathrm{CD}^{+}$(DP, double positive), and $\mathrm{CD} 8+$ along with the uptake of 7-aminoactinomycin D (7-AAD), which shows apoptosis for individual phenotypes. Statistical analysis was performed using the general linear model (GLM) analysis of variance (ANOVA) from the SAS package (SAS Institute Inc., Cary, North Carolina). Significant differences among each experimental group with $P<0.05$ were reported.

Mice brains were split into right and left halves after removal. The left half was used for tissue cyst enumeration and $\mathrm{MeHg}$ quantification as described previously (Lindsay et al., 1998; King et al., 2003). Paraffin blocks were prepared from the right half of the brains, and from them separate slides were stained with hematoxylin and eosin (H\&E) and labeled with TdT-mediated deoxyuridine triphosphate (dUTP)-X nickend marker (terminal deoxynucleotidyl transferase-mediated deoxyuridine triphosphate nick-end labeling [TUNEL], Roche Molecular Biochemicals, Mannheim, Germany), and antibody to glial fibrillary acidic protein (GFAP) (Neuen-Jacob et al., 1993) was introduced, as described previously (King et al., 2003).

Mice were examined for clinical deficits indicative of neurotoxicity after $\mathrm{MeHg}$ exposure (days 0, 2, 4, 7, 10, and 13). Examinations were done during the dark cycle of the standard 12-hr light-12-hr dark cycle, using a red light lamp for observation. Behavioral response analyses were obtained and modified using an established protocol from the Laboratory for Neurotoxicity Studies at Virginia-Maryland Regional College of Veterinary Medicine (King et al., 2003), derived from original procedures for behavioral studies in rodents by Moser et al. (1988).

Body weights of the mice remained unchanged throughout dosing among all experimental groups when compared with each other or with control (group means 23-25 g). Thymus weights were decreased in the $\mathrm{MeHg}$-only group $(25.4 \pm 5.2 \mathrm{mg})$ compared with controls $(43.1 \pm 4.4$ $\mathrm{mg} ; P=0.08)$ but not in other groups. Spleen weights showed a marked increase over values from control mice $(73.2 \pm 3.4 \mathrm{mg})$ and values from mice given $T$. gondii only $(78.5 \pm 4.8 \mathrm{mg})$ in the groups exposed to $\mathrm{MeHg}(113.9 \pm 13.0 \mathrm{mg}$ in MeHg-only mice; $P<0.05 ; 118.5 \pm$ $8.2 \mathrm{mg}$ in T.gondii-MeHg mice; $P<0.05)$. Splenic cell viability showed a significant decrease in mice infected with $T$. gondii with or without $\mathrm{MeHg}$ exposure $(P<0.05)$. Viability of cells in the thymus was unchanged (Fig. 1).

Absolute numbers of cells in the thymus of mice exposed to $\mathrm{MeHg}$ with or without a $T$. gondii infection showed a significant decrease in total numbers of $\mathrm{CD}^{+}{ }^{+} \mathrm{CD} 8{ }^{-}, \mathrm{CD} 4{ }^{-} \mathrm{CD}^{+}$, and $\mathrm{CD} 4{ }^{+} \mathrm{CD} 8{ }^{+}$T-cells $(P$ $<0.05$ ) when compared with control and $T$. gondii-infected groups (Table I). The $\mathrm{CD}^{-}{ }^{-} \mathrm{CD} 8^{-}$cell population of the thymus was also reduced, although not significantly. Each of the subpopulations of splenocytes from mice coexposed to $T$. gondii and $\mathrm{MeHg}$ was reduced, although these reductions were not statistically significant. When expressed as a percentage of total cells (Table II), flow cytometric analysis of thymocyte subpopulations of mice exposed to $\mathrm{MeHg}$ with a concurrent $T$. gondii infection showed a significant increase in the $\mathrm{CD}^{-} \mathrm{CD}^{-}$ 
Cell Viability of Thymus and Spleen in CBA/J Mice

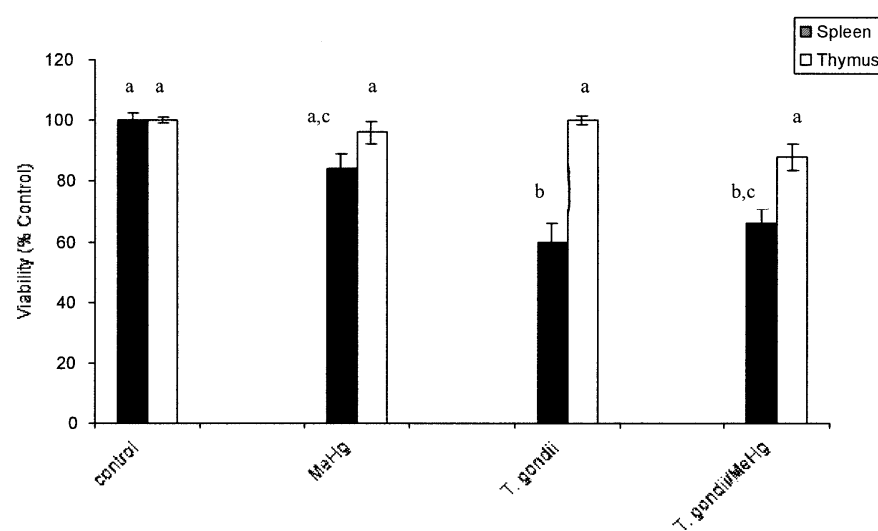

FIGURE 1. Mice dosed with $8 \mathrm{mg} / \mathrm{kg}$ body weight methylmercury ( $\mathrm{MeHg}$ ) every 2-3 days for 18 days, after a 6-wk Toxoplasma gondii chronic infection. Sacrificing was day 17 or 18 post $\mathrm{MeHg}$ exposure. Viability of cells, expressed as percentage of total cells present within the spleen and thymus, was determined by flow cytometric analysis. In the spleen, $T$. gondii decreased viability to $60 \%$ of control. Viability in spleen cells from this group of mice was also different from $\mathrm{MeHg}$ treated mice $(P<0.05)$. Decreases were seen in the spleen of mice $T$. gondii/MeHg mice. Each experimental group contained an $\mathrm{n}=10$. Comparisons among groups were performed using a Tukey's non-parametric test. For each organ no shared letters above bars implies that groups are significantly different $(P<0.05)$.

T-cell subpopulation when compared with control or $T$. gondii alone ( $P$ $<0.05$ ). Toxoplasma gondii-infected mice had a marked increase in the percentage of non- $T$ cell subpopulation and a decrease in the $\mathrm{CD} 4^{+} \mathrm{CD} 8^{-} \mathrm{T}$ cells of the spleen when compared with both control and $\mathrm{MeHg}$-exposed mice (Table II). Splenic T-cell absolute numbers showed no significant change among any of the experimental groups.

A review of $\mathrm{H} \& \mathrm{E}$-stained slides from the brains of mice that were given multiple $8-\mathrm{mg} / \mathrm{kg}$ doses of $\mathrm{MeHg}$ for 17 days did not reveal significant lesions in the brain in animals that were given $\mathrm{MeHg}, T$. gondii, or the combination of these 2 agents, or in vehicle controls. In addition, the cerebellar cortical lesions of granule cell necrosis-apoptosis (Nagashima et al., 1996) were absent in the MeHg-dosed mice regardless of the presence of a $T$. gondii infection. There were neither consistent astrocytic alterations noted in these sections using GFAP immunohistochemical staining nor any detectable apoptotic changes using the TUNEL assay on nervous or immune tissue.

Flow cytometric analysis with a triple color stain allowed for determination of apoptosis in individual T-cell subpopulations of the thymus and spleen. The only significant change in thymocytes was an increase in early apoptotic $\mathrm{CD} 4^{+} \mathrm{CD} 8^{-} \mathrm{T}$ cells in mice exposed to $T$. gondii$\mathrm{MeHg}$ (from $24.1 \pm 3.9 \%$ in controls to $42.3 \pm 5.5 \% ; P<0.05$ ). The CD4 ${ }^{-} \mathrm{CD} 8^{+}$and $\mathrm{CD} 4{ }^{+} \mathrm{CD} 8{ }^{+} \mathrm{T}$-cell subpopulations did not undergo any significant change.
Toxoplasma gondii-infected mice had more significant changes in apoptosis of spleen cells, with decreases in percentages of live $\mathrm{CD}^{+} \mathrm{CD}^{-}$and non- $\mathrm{T}$ cells and increases in late apoptotic $\mathrm{CD} 4^{+} \mathrm{CD} 8^{-}$ and $\mathrm{CD}^{-}{ }^{-} \mathrm{CD}^{+}{ }^{+} \mathrm{T}$-cell subpopulations. Not all these changes were observed in mice exposed to both $T$. gondii and $\mathrm{MeHg}$. Apoptosis staining (TUNEL) of the spleen and thymus revealed no difference between treated and nontreated groups of mice (data not shown).

Analysis for testing of repeated behavioral responses of mice exhibiting a certain response on each day was performed. Multiple-day analysis indicated that 4 of 27 responses showed a change when comparing $\mathrm{MeHg}$-only-exposed mice to $T$. gondii-MeHg-coexposed mice (click response, menace response, agility on a wooden rod, and vocalization). Of the 10 mice in each group, $70 \%, 10 \%, 70 \%$, and $40 \%$ given only $\mathrm{MeHg}$ demonstrated differences in the above-listed responses, respectively, but only on day 10 . Mice coexposed to $T$. gondii-MeHg showed signs of vocalization when handled ( 3 of the 10 mice) on day 10 . Mice infected with $T$. gondii-only or vehicle control showed no neurobehavioral abnormality before sacrifice on day 17 or 18

Although the number of tissue cysts was $3.5 \pm 1.1$ in mice exposed to $T$. gondii only and $5.6 \pm 1.1$ in mice given $T$. gondii- $\mathrm{MeHg}$, tissue cyst counts were not significantly different between the groups. Lesion scoring was similar for all groups. Coexposed mice had significantly lower brain levels of $\mathrm{MeHg}$ than the $\mathrm{MeHg}$-only-exposed mice $(0.31$ \pm 0.03 vs. $0.68 \pm 0.17 \mathrm{ppm}$, respectively). Kidney levels were $19.2 \pm$ $3.9 \mathrm{ppm}$ in mice treated with $\mathrm{MeHg}$ only and $22.1 \pm 5.2 \mathrm{ppm}$ in mice treated with $T$. gondii-MeHg. Levels of $\mathrm{MeHg}$ in mice not experimentally treated with $\mathrm{MeHg}$ were undetectable.

The present study examined the effects of multiple exposures to $\mathrm{MeHg}$ on a chronic T. gondii infection. Multiple low-dose effects in mice were less notable than when a single high dose of $\mathrm{MeHg}$ was given (King et al., 2003). For example, multiple, lower-dose exposure to $\mathrm{MeHg}$ did not increase brain tissue cysts of $T$. gondii or alter morphological effects of the infection. Because both these agents have detrimental effects on similar systems, nervous and immune (M. Aschner and J. L. Aschner, 1990; Daubener and Hadding, 1997), it was expected that the coexistence of a chronic infection and an environmental contaminant such as those examined here would worsen the initial disease state. However, the results of the present study showed that CBA/J mice demonstrated immunotoxic response to $\mathrm{MeHg}$ exposure but not a relapse of chronic toxoplasmosis.

Immune effects after multiple exposure of $\mathrm{MeHg}$ were demonstrated by a marked increase in the splenic weights of mice exposed to $\mathrm{MeHg}$ with or without a $T$. gondii infection, whereas thymus weights were decreased for the same mice. It was noteworthy that thymus weight was only different in those mice receiving multiple low doses of $\mathrm{MeHg}$ without a concurrent $T$. gondii infection. Alterations of organ weights are often primary indicators of potential immunotoxicity (Descotes, 1999). The cellularity decrease observed in the thymus of mice exposed to $\mathrm{MeHg}$ with or without a $T$. gondii infection is indicative of the depletion observed in lymphoid organs after immunosuppression. Mice coexposed to $T$. gondii and $\mathrm{MeHg}$ had a decreased splenic cellularity when compared with mice infected with only $T$. gondii in the present study. This result was different from the results of a previous study with a single high dose of $\mathrm{MeHg}$ (King et al., 2003).

The interaction of $T$. gondii and $\mathrm{MeHg}$ could be associated with effects on the immune system. Methylmercury in combination with $T$.

TABLE I. Absolute numbers of T-cell subpopulations in thymus from mice infected with Toxoplasma gondii or T. gondii and MeHg.* All data are expressed as mean $\times 10^{6}$ cells $\pm \mathrm{SE}$.

\begin{tabular}{|c|c|c|c|c|c|}
\hline Treatment & $\begin{array}{c}\text { Total } \\
\text { cellularity }\end{array}$ & \multicolumn{4}{|c|}{ Thymic T-cell subpopulation } \\
\hline Control & $86.4 \pm 8.4$ & $21.8 \pm 7.0$ & $4.1 \pm 0.5$ & $2.9 \pm 0.7$ & $57.7 \pm 4.7$ \\
\hline T. gondii & $82.5 \pm 4.9$ & $11.5 \pm 2.3$ & $4.6 \pm 0.8$ & $3.5 \pm 1.8$ & $64.7 \pm 5.9$ \\
\hline T. gondii- $\mathrm{MeHg}$ & $48.3 \pm 10.8 \dagger \ddagger$ & $6.7 \pm 2.8$ & $2.7 \pm 0.6+\neq$ & $2.0 \pm 0.7$ & $37.7 \pm 9.2 \neq$ \\
\hline
\end{tabular}

* Female CBA/J mice exposed every 2-3 days to $8 \mathrm{mg} / \mathrm{kg} \mathrm{MeHg}$ for 18 days (n = 10).

$\dagger$ Statistically significant difference $(P<0.05)$ when compared with control.

† Statistically significant difference $(P<0.05)$ when compared with $T$. gondii-infected mice. 
TABLE II. T-cell subpopulations as a percentage of total cells in the thymus and spleen of mice infected with Toxoplasma gondii or T. gondii and MeHg.* All data are expressed as percent mean \pm SE.

Percentages of T-cell subpopulations

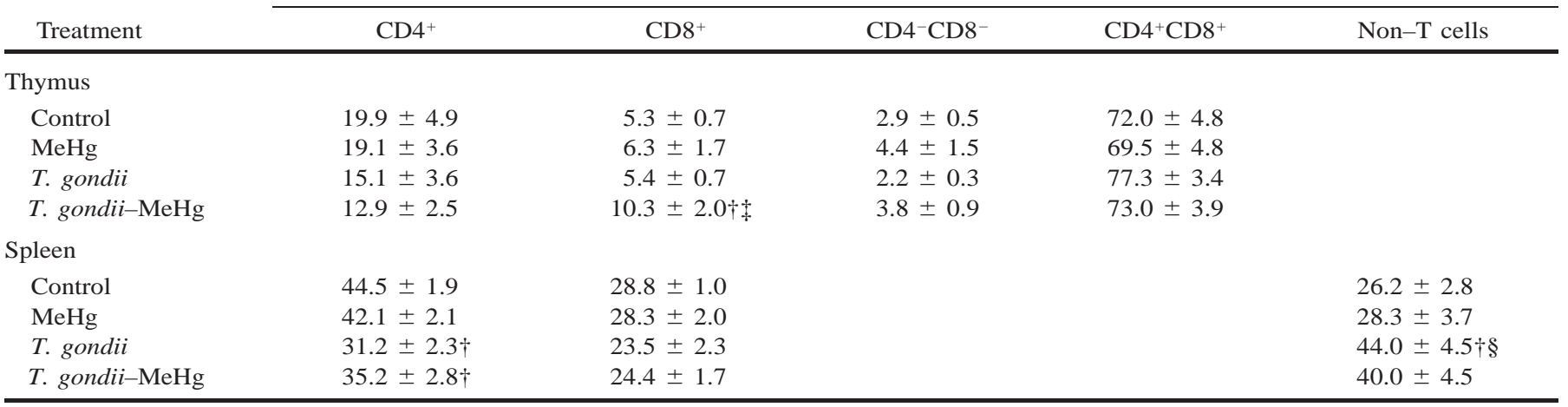

* Female CBA/J mice exposed every $2-3$ days to $8 \mathrm{mg} / \mathrm{kg} \mathrm{MeHg}$ for 18 days $(\mathrm{n}=10)$. Total cellularity of splenic cells was $52 \pm 6.5,76.9 \pm 41.7,69.0 \pm 6.3$, and

$31.6 \pm 6.0$ in control, $\mathrm{MeHg}, T$. gondii, and $T$. gondii-MeHg-treated mice, respectively.

$\dagger$ Statistically significant difference $(P<0.05)$ when compared with control.

$\dashv$ Statistically significant difference $(P<0.05)$ when compared with $T$. gondii-infected mice.

$\S$ Statistically significant difference $(P<0.05)$ when compared with $\mathrm{MeHg}$-treated mice.

gondii caused a significant increase $(P<0.05)$ in the percentage of mature $\mathrm{CD} 4{ }^{-} \mathrm{CD} 8{ }^{+} \mathrm{T}$ cells in the thymus, showing no variation in the number found in the spleen. These single positive cells are the mature $\mathrm{T}$ cells that then migrate to the periphery. These data indicate that there is either a lack of migration of $\mathrm{CD}^{-}{ }^{-} \mathrm{CD} 8^{+} \mathrm{T}$ cells or a possible increased production of these cells at this subchronic dose of $\mathrm{MeHg}$, or both. These $\mathrm{T}$ cells $\left(\mathrm{CD} 4^{-} \mathrm{CD} 8^{+}\right)$are responsible for killing cells infected by viruses, tumors, or toxicants. Other studies have found that low dosages of $\mathrm{MeHg}(10 \mathrm{ppm})$ did not affect memory of lymphocytes and that $\mathrm{T}$ rather than $\mathrm{B}$ cells are generally affected when a secondary immune response is altered after exposure to subclinical amounts of environmental contaminants (Koller et al., 1980).

Examination of mice exposed to low, multiple doses of $\mathrm{MeHg}$ for 18 days showed that mouse body weights remained unchanged throughout dosing. In experimental $\mathrm{MeHg}$ poisoning in rats and mice, the first adverse symptom noted is the loss of body weight (Suzuki and Miyama, 1971). Results obtained in the present study were not in agreement with the results of Suzuki and Miyama (1971), although our previous study with a single, higher $\mathrm{MeHg}$ dose was (King et al., 2003). The responses that indicated alterations in nervous system behavior were negligible in mice coexposed to T. gondii- $\mathrm{MeHg}$ and were noted only on day 10 after repeated exposure to $\mathrm{MeHg}$ alone. Other studies confirm the same pattern of neurological symptoms (Suzuki and Miyama, 1971). Massive doses would be expected to produce a variety of symptoms in a short time, and then the animal would die, whereas on exposure to lower doses, such as ours, the symptoms of $\mathrm{MeHg}$ poisoning are delayed (Bagenstose et al., 2001). It is possible that behavioral abnormalities could appear at time points beyond the 17 or 18 days of our experiment, but time of death was determined by the need to gather endpoints before the mice succumbed to the chronic $T$. gondii infection. This usually occurs within between 8 and 9 wk PI (Suresh et al., 1991).

Histological examination of brain tissue did not show any lesion, tissue cyst enumeration, or glial scarring that would have been indicative of $\mathrm{MeHg}$ poisoning. Again, more time may be needed before these events occur (Suzuki and Miyama, 1971). Brains of mice exposed to $\mathrm{MeHg}$ with a concurrent $T$. gondii contained less mercury than those given only MeHg. The level in the kidneys was higher than that found in the brain, indicating the animals' ability to continue to excrete mercury. In this study, the quantity of mercury in the brain $(0.68 \mathrm{ppm})$ was, however, significantly higher than the $0.35 \mathrm{ppm}$ observed 7 days after a $20-\mathrm{mg} / \mathrm{kg}$ body weight $\mathrm{MeHg}$ dose. Also notable was the difference in $\mathrm{MeHg}$ level in the brains of mice coexposed to T. gondii and $\mathrm{MeHg}$, i.e., $0.31 \mathrm{ppm}$ in the present study and $0.04 \mathrm{ppm}$ with a single $\mathrm{MeHg}$ exposure (King et al., 2003).

A plausible relationship between chronic parasitic infections and environmental contaminant exposure has not been explored previously because of the lack of relevant epidemiology studies (Clarkson et al.,
1983; Bagenstose et al., 2001). However, an earlier study in an animal model demonstrated enhanced immunotoxic effects when mice were concurrently exposed to dioxin and T. gondii (King et al., 2000). The present study is novel in that it evaluates in vivo responses of both the immune and the nervous systems after multiple exposures to a relatively low dose of an environmental contaminant that can cause neurological impairment, which has the potential to worsen over time with concurrent parasitic infections (Silbergeld et al., 2000). The results of the present study demonstrate that CBA/J mice undergo immunotoxicity because of $\mathrm{MeHg}$ exposure but not a relapse of chronic toxoplasmosis.

We thank Robert Gogal and Bernard Jortner for professional assistance with immunotoxicological and pathological studies, respectively. We are also grateful to Daniel Ward for statistical support, Joan Kalnitsky for flow cytometric analysis, and Barbara Wise for atomic absorption analysis. This work was supported by NIH Grant F36GM20301 and Virginia-Maryland Regional College of Veterinary Medicine.

\section{LITERATURE CITED}

AsCHNER, M., AND J. L. AsChNER. 1990. Mercury neurotoxicity: Mechanisms of blood-brain barrier transport. Neuroscience and Biobehavioral Reviews 14: 169-176.

Bagenstose, L. M., M. M. Mentink-Kane, A. Brittingham, D. M. Mosser, AND M. Monestier. 2001. Mercury enhances susceptibility to murine leishmaniasis. Parasite Immunology 23: 633-640.

Belanger, F., F. Derouin, L. Grangeot-Keros, and L. Meyer. 1999. Incidence and risk factors of toxoplasmosis in a cohort of human immunodeficiency virus-infected patients: 1988-1995. HEMOCO and SEROCO study groups. Clinical and Infectious Disease 28: 575-581.

Clarkson, T. W., B. Weiss, and C. Cox. 1983. Public health consequences of heavy metals in dump sites. Environmental Health Perspectives 48: 113-127.

Daubener, W., ANd U. Hadding. 1997. Cellular immune reactions directed against Toxoplasma gondii with special emphasis on the central nervous system. Medical Microbiology and Immunology 185: $195-206$.

Descotes, J. 1999. An introduction to immunotoxicology. Taylor \& Francis, Philadelphia, Pennsylvania, 183 p.

Gazzinelli, R. T., I. Eltoum, T. A. Wynn, And A. Sher. 1993. Acute cerebral toxoplasmosis is induced by in vivo neutralization of TNFalpha and correlates with the down-regulated expression of inducible nitric oxide synthase and other markers of macrophage activation. Journal of Immunology 151: 3672-3681.

King, M. D., D. S. Lindsay, M. F. Ehrich, AND M. NAGarkatti. 2000. Effect of 2,3,7,8-tetrachloro-di-benzo-p-dioxin on T cell subpopu- 
lations in the thymus and spleen of mice with chronic Toxoplasma gondii infection. International Journal of Toxicology 19: 323-329. , S. Holladay, AND M. Ehrich. 2003. Neurotoxicity and immunotoxicity assessment in $\mathrm{CBA} / \mathrm{J}$ mice with chronic Toxoplasma gondii infection and single dose exposure to methylmercury. International Journal of Toxicology 22: 1-9.

Koller, L. D., J. G. RoAn, AND J. A. Brauner. 1980. Methylmercury: Effects on B-lymphocyte receptors and phagocytosis of macrophages. Journal of Environmental Pathology and Toxicology 3: 407-411.

Lindsay, D. S., S. D. Lenz, C. C. Dykstra, B. L. Blagburn, and J. P. DUBEY. 1998. Vaccination of mice with Neospora caninum: Response to oral challenge with Toxoplasma gondii oocysts. Journal of Parasitology 84: 311-315.

Moser, V. C., J. P. McCormick, J. P. Creason, and R. C. MacPhail. 1988. Comparison of chlordimeform and carbaryl using a functional observational battery. Fundamental and Applied Toxicology 11: 189-206.

MoszCZYNSKI, P. 1997. Mercury compounds and the immune system: A review. International Journal of Occupational Medicine and Environmental Health 10: 247-258.

Nagashima, K., Y. Fuji, T. Tsukamoto, S. Nukuzuma, M. Satoh, and M. FuJitA. 1996. Apoptotic process of cerebellar degeneration in experimental methylmercury intoxication of rats. Acta Neuropathologica 91: 72-77.
Neuen-Jacob, E., C. Figge, G. Arendt, B. Wendtland, B. Jacob, and W. WeCHSLER. 1993. Neuropathological studies in the brains of AIDS patients with opportunistic diseases. International Journal of Legal Medicine 105: 339-350.

Ogata, A., J. Nishinira, T. Suzuki, K. Nagashima, and K. Tashiro. 1998. Identification of macrophage migration inhibitory factor mRNA expression in neural cells of the rat brain by in situ hybridization. Neuroscience Letters 246: 173-177.

Schaumburg, H. H., AND P. S. SPENCER. 2000. Classification of neurotoxic responses based on vulnerability of cellular sites. Neurological and Clinical 18: 517-524.

Silbergeld, E. K., J. B. SACCi, And A. F. Azad. 2000. Mercury exposure and murine response to Plasmodium yoelii infection and immunization. Immunopharmacology and Immunotoxicology 22: 685-695.

SuRESH, K., J. W. MAK, AND H. S. YoNG. 1991. Immune response in acute Toxoplasma infection of $\mathrm{Balb} / \mathrm{C}$, ICR and $\mathrm{CBA} / \mathrm{J}$ mice. Southeast Asian Journal of Tropical Medicine and Public Health 22: $452-454$.

SuZUKI, T., AND T. MiYAMA. 1971. Neurological symptoms and mercury concentration in the brain of mice fed with methylmercury salt. Industrial Health 9: 51-58.

U.S. Department of Health and Human Services. 1994. Toxicological profile for mercury (update). Agency for Toxic Substances and Disease Registry, Atlanta, Georgia, 617 p.

\title{
Meningoencephalitis Associated with an Unidentified Apicomplexan Protozoan in a Pacific Harbor Seal
}

\author{
J. M. Lapointe*, P. J. Duignan†, B. C. Barrł, A. K. Petrich§, D. W. MacPherson\|, F. M. Gulland\#, and J. P. Dubeyף, University of \\ California-Davis, Davis, California 95616; *Present address: 393 Pequot Avenue, New London, Connecticut 06320; †Institute of Veterinary, \\ Animal, and Biomedical Sciences, Massey University, New Zealand; ‡California Animal Health and Food Safety Laboratory System, Davis, \\ California 95616; \$Microbiology Department, St. Joseph's Healthcare, Hamilton, Ontario, Canada L8N 4A6; |Centre for Emergency \\ Preparedness and Response, Health Canada, Ottawa, Ontario, Canada K1A OK9; \#The Marine Mammal Center, Marin Headlands, Sausalito, \\ California 94965; ПParasite Biology, Epidemiology, and Systematics Laboratory, USDA-ARS, Beltsville, Maryland 20705. e-mail: jean- \\ martin_lapointe@groton.pfizer.com
}

ABSTRACT: A Pacific harbor seal (Phoca vitulina richardsii) was found on the central California coast with neurologic signs and labored breathing, which were unresponsive to treatment. Necropsy revealed a nonsuppurative necrotizing meningoencephalitis, a multilocular thymic cyst, and nonsuppurative cystitis and renal pyelitis. Microscopic examination revealed protozoans in the brain, thymic cyst, and bladder mucosa. Ultrastructurally, the protozoal tachyzoites were different from those of Neospora caninum, Toxoplasma gondii, and Sarcocystis neurona; the rhoptries were small and had electron-dense contents, and the organism divided by endodyogeny. Specific antibodies were not detected in serum using agglutination ( $N$. caninum, $T$. gondii) and immunoblot assays ( $S$. neurona). Immunohistochemistry for these organisms was negative. Polymerase chain reaction on brain tissue using specific primers did not amplify $T$. gondii deoxyribonucleic acid. The meningoencephalitis in this seal thus appears to have been caused by a novel protozoan.

Infections of wild mammals by apicomplexan protozoans, including Toxoplasma gondii, Neospora caninum, and Sarcocystis neurona, have been reported regularly over the past 20 yr. Several pinniped species have been found to be susceptible to $T$. gondii or $S$. neurona, including harbor seals (Phoca vitulina richardsii) (Van Pelt and Dietrich, 1973; Lapointe et al., 1998), northern fur seals (Callorhinus ursinus) (Holshuh et al., 1985), and sea otters (Enhydra lutris) (Lindsay et al., 2001). The target organs vary, but the central nervous system is often severely affected. Simultaneous infections by $T$. gondii and $S$. neurona have also been observed (Lindsay et al., 2001; Miller et al., 2001). The present report describes a harbor seal with meningoencephalitis associated with an apicomplexan protozoan different from $T$. gondii, $N$. caninum, and S. neurona.

In June 1994, a juvenile female Pacific harbor seal was found alive but weak on the seashore near Bolinas, Marin County, California, and was brought to the Marine Mammal Center in Sausalito, California. It was $74 \mathrm{~cm}$ in length and weighed $21.6 \mathrm{~kg}$; the umbilical stump was not visible. On the basis of appearance and stranding location, its age was estimated at 2-4 wk. It was given supportive treatment for 5 days, including nasogastric intubation and feeding, but on the last day its breathing was labored and it had dilated pupils and suffered seizures. It was given $0.5 \mathrm{mg}$ of diazepam intravenously (i.v.) and $20 \mathrm{mg}$ dexamethasone i.v. but remained unresponsive and was killed shortly thereafter with $3 \mathrm{ml}$ pentobarbital i.v.

On necropsy, a $10-\mathrm{cm}$ diameter mass was found within the cranial mediastinum, containing multiple cystic cavities filled with purulent exudate. The cerebral cortex appeared swollen, pale, and edematous.

For histology, sections of brain, spinal cord, mediastinal mass, liver, lung, kidney, bladder, heart, spleen, stomach, intestine, lymph nodes, adrenals, and pancreas were fixed in $10 \%$ buffered formalin and were embedded in paraffin; $5-\mu \mathrm{m}$ sections were stained with hematoxylineosin (HE) and examined using light microscopy.

Sections of cerebral cortex were also examined using transmission electron microscopy. Formalin-fixed tissue was postfixed in $1 \%$ osmium tetroxide, dehydrated through graded alcohols and propylene oxide, and embedded in epon-araldite resin. Sections 600 to 900 A thick were stained with uranyl acetate-lead citrate and examined with a transmission electron microscope at $80 \mathrm{kV}$. 


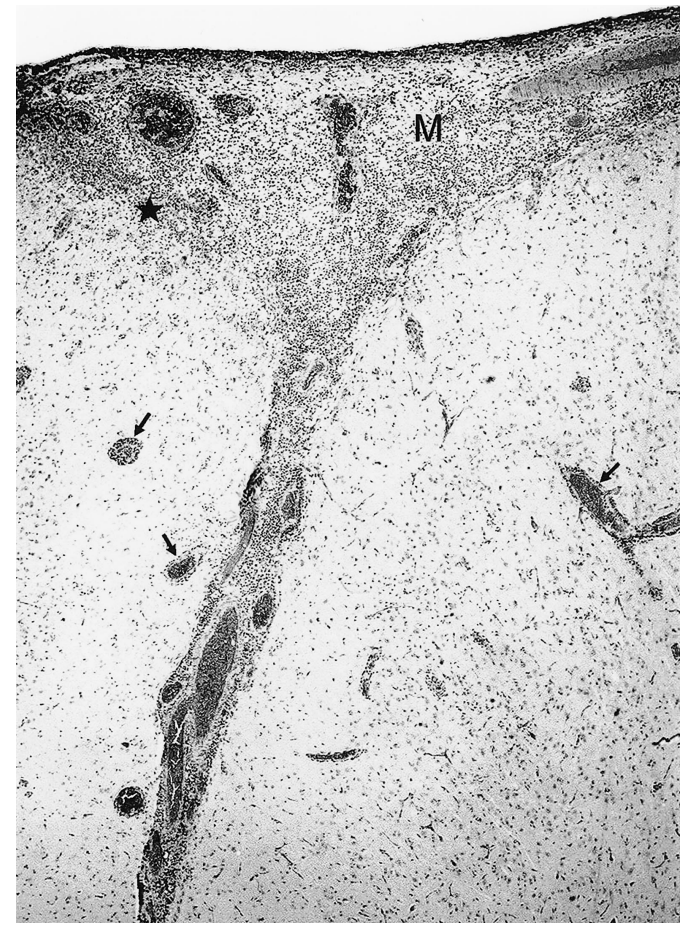

FIGURE 1. Histologic section of cerebral cortex, Pacific harbor seal. The meninges (M) are thickened by edema and an abundant inflammatory cell infiltrate, sometimes extending into the cortical gray matter (star). Blood vessels within the neuropil are surrounded by cuffs of inflammatory cells (arrows). HE stain.

Sections of cerebral cortex, mediastinal mass, kidney, bladder, lung, and lymph nodes were immunohistochemically stained using a labeled streptavidin-biotin detection system. Sections were deparaffinized and pretreated with $0.4 \%$ pepsin in acidified water $(\mathrm{pH} \mathrm{3.3)}$ ) for $15 \mathrm{~min}$ at $37 \mathrm{C}$. They were then incubated for $60 \mathrm{~min}$ at room temperature with 1 of the rabbit polyclonal antibodies (California Animal Health and Food Safety Laboratory [CAHFS], Davis, California) anti-S. neurona at a 1:1,600 dilution, anti-S. falcatula at 1:1,600, anti-S. cruzi at 1:200, anti- $N$. caninum at $1: 400$, and anti- $T$. gondii at 1:1,500, as described previously by Dubey et al. (2001). The slides were then incubated with a biotinylated goat anti-rabbit IgG antibody at a 1:500 dilution, after which they were immunostained with a horseradish peroxidase-streptavidin-biotin detection system using aminoethylcarbazole as the chromogen (Envision ${ }^{\circledR}$, Dako Corporation, Carpinteria, California). For all antibodies, suitable negative and positive tissue controls were used. The stains were made at both the CAHFS and the United States Department of Agriculture-Parasite Biology, Epidemiology, and Systematics Laboratory (Beltsville, Maryland).

For polymerase chain reaction (PCR)-based detection of $T$. gondii, a previously published technique targeting the B1 multicopy gene was used, with minor modifications (Burg et al., 1989). Five $20-\mu \mathrm{m}$-thick sections of cerebral cortex were used for total deoxyribonucleic acid (DNA) extraction, using the tissue protocol from the QIAamp DNA Mini Kit (Qiagen, Mississauga, Ontario, Canada). Samples of 2 and 5 $\mu l$ of the DNA extract were added to a $50-\mu 1$ PCR reaction containing $10 \mathrm{mM}$ Tris- $\mathrm{HCl}, \mathrm{pH} 8.3 ; 50 \mathrm{mM} \mathrm{KCl} ; 2.5 \mathrm{mM} \mathrm{MgCl}_{2} ; 200 \mu \mathrm{M}$ deoxynucleoside triphosphates; $1 \mu \mathrm{M}$ each of primers P1 (5'-GGA ACT GCA TCC GTT CAT GAG- $\left.3^{\prime}\right)$ and P4 (5'-TCT TTA AAG CGT TCG TGG TC-3'), and $1.25 \mathrm{U}$ of AmpliTaq Gold polymerase (Perkin-Elmer, Boston, Massachusetts). Amplification was performed under the following conditions: $94 \mathrm{C}$ for $10 \mathrm{~min}$, then 40 cycles of $30 \mathrm{sec}$ at $94 \mathrm{C}, 30$ $\mathrm{sec}$ at $57 \mathrm{C}$, and $15 \mathrm{sec}$ at $72 \mathrm{C}$; then a final elongation at $72 \mathrm{C}$ for 10 $\mathrm{min}$. Ten microliters of the reaction was run in a $2 \%(\mathrm{w} / \mathrm{v})$ agarose gel at $140 \mathrm{~V}$ for $45 \mathrm{~min}$. The gel was stained with ethidium bromide and examined under ultraviolet light. Positive and negative control reactions, as well as a positive control spiked with the harbor seal sample

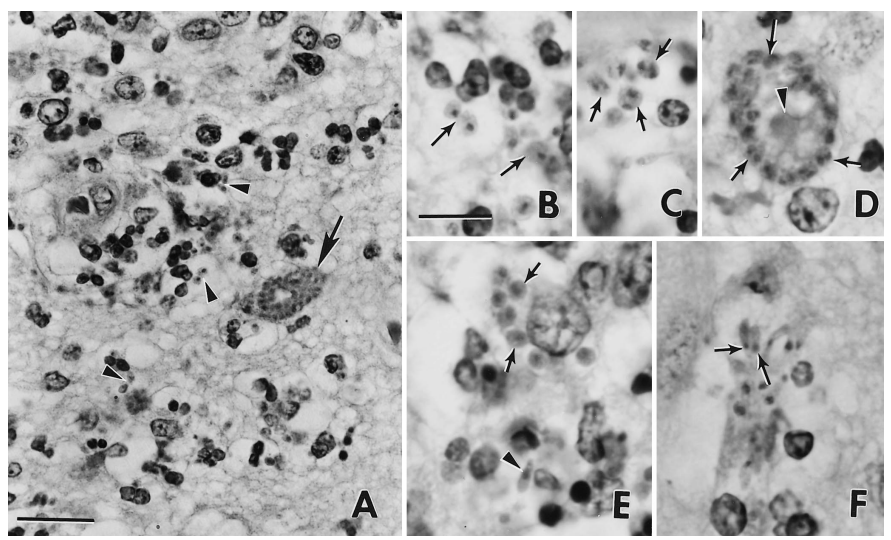

FIGURE 2. Histologic sections of cerebral cortex, Pacific harbor seal. (A) Protozoan tachyzoites, individually (arrowheads) or in a group (arrow), in a focus of inflammation. (B) Tachyzoites with a central nucleus (arrows). (C) Tachyzoites dividing into 2 (arrows). (D) Synchronous division of organisms (arrows), with a residuallike body in the center (arrowhead). (E) Globular zoites (arrows) and an elongated zoite (arrowhead). (F) Elongated organisms with terminal nuclei (arrows). HE stain. Bar in $\mathbf{A}=20 \mu \mathrm{m}$, bars in $\mathbf{B}-\mathbf{F}=10 \mu \mathrm{m}$.

(to test for PCR inhibitors in the DNA extract), were run along with the test harbor seal samples.

Serum taken before death was assayed for the presence of antibodies against $T$. gondii, $N$. caninum, and $S$. neurona. For $T$. gondii and $N$. caninum, modified agglutination tests were used, as previously described (Dubey and Desmonts, 1987; Packham et al., 1998). For $S$ neurona, a previously described Western blot technique was used (Lapointe et al., 1998).

In the brain, there was a necrotizing meningoencephalitis, most severe in the cerebral cortex. The leptomeninges were markedly thickened by edema and a mixed inflammatory cell infiltrate of macrophages, lymphocytes, and neutrophils (Fig. 1). These cells surrounded and infiltrated the walls of the meningeal arterioles and venules. The inflammatory infiltrate extended multifocally into the underlying cortical gray matter, associated with edema and malacia. Numerous small vessels within the neuropil were surrounded by perivascular cuffs of inflammatory cells. Meningeal and perivascular infiltration were also present in the midbrain, cerebellum, brainstem, and spinal cord but were milder and without marked infiltration of the neuropil.

Protozoans were observed in the meninges and in the inflamed areas of cortical gray matter (Fig. 2A). On HE-stained sections, the organisms stained lighter than host cells and thus were difficult to recognize. Tachyzoites were observed singly or in groups. They were generally oval to globular and about 2-3 $\mu \mathrm{m}$ in diameter; elongate tachyzoites were rarely observed (Fig. 2D). The organisms were seen to divide into 2, often by simultaneous endodyogeny (Fig. 2B, D). Groups of tightly packed protozoans were noted, without a clearly visible cyst wall around them. One group containing elongate organisms was seen; in these the nucleus was terminal (Fig. 2F).

The cranial mediastinal mass consisted of multiple irregular-shaped areas of epithelial proliferation, often forming cystic cavities. These cysts had a clear center containing numerous vacuolated macrophages and neutrophils and were lined by a stratified squamous nonkeratinizing epithelium resembling thymic epithelial cells. The cystic cavities were separated by bands of immature fibrovascular tissue infiltrated by abundant macrophages, lymphocytes, and plasma cells. This lesion was interpreted as a multilocular thymic cyst (Suster and Rosai, 1991). Some of the macrophages in the cyst contained intracellular protozoal organisms, similar to those observed in the brain.

In the kidney, there was a moderate nonsuppurative pyelitis, with a diffuse bandlike infiltration by macrophages, lymphocytes, and plasma cells underlying the lining epithelium of the pelvic areas. The pelvic epithelium was mildly infiltrated with scattered lymphocytes. In the bladder, there was a similar pattern of inflammation, with a mild to moderate bandlike infiltrate of mononuclear cells under the epithelium 


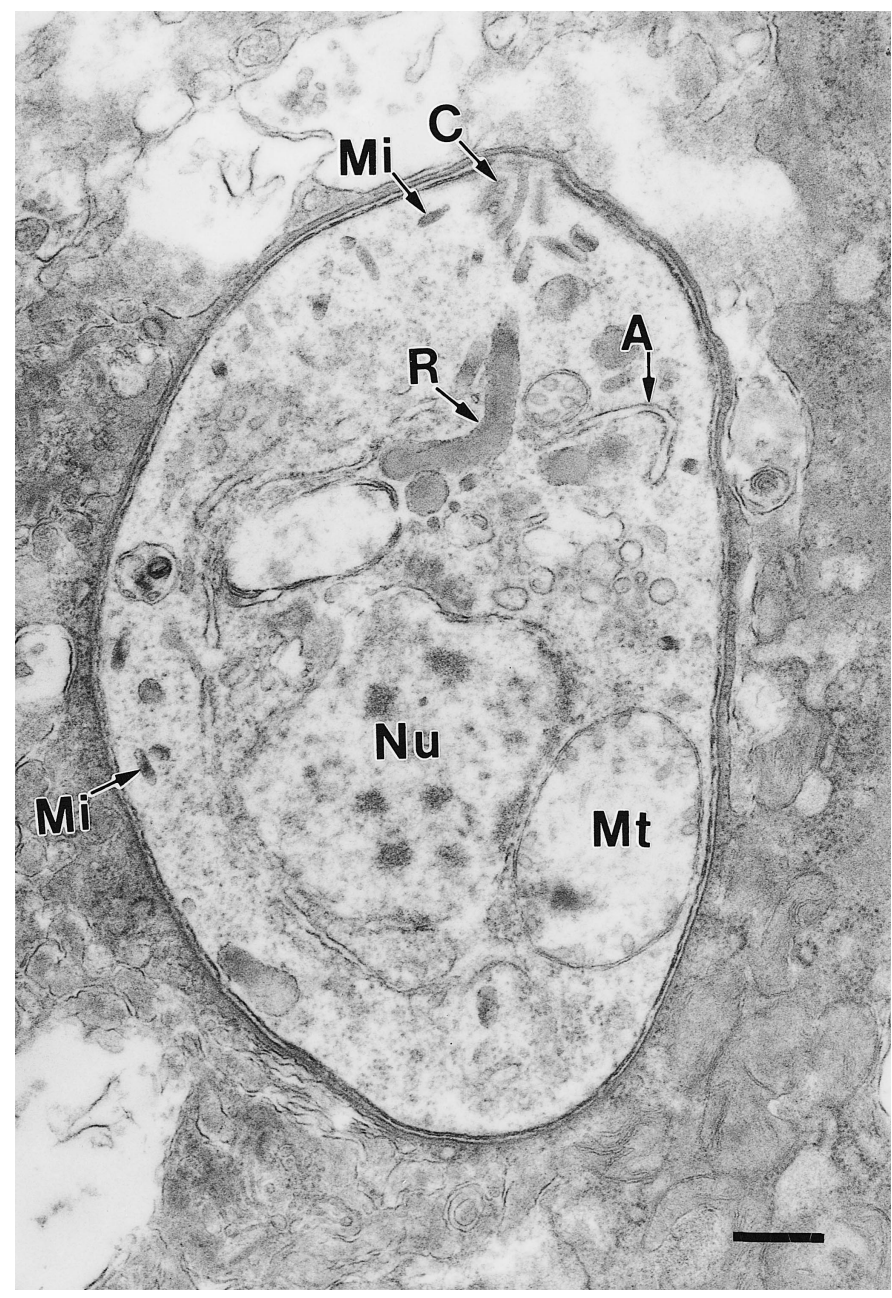

FIGURE 3. Transmission electron micrograph of a zoite, showing an early stage of endodyogeny. Note conoid (C), few scattered micronemes (Mi), a rhoptry (R) with its bulbous end bent at a right angle, nucleus $(\mathrm{Nu})$, mitochondrion (Mt), and the formation of anlagen of a daughter zoite (A). Bar $=500 \mathrm{~nm}$.

and mild lymphocytic epithelial infiltration. A few protozoans were noted within the inflammatory infiltrate of the bladder.

In both adrenal glands, there were multifocal areas of infiltration of the cortex with macrophages and lymphocytes, sometimes effacing focally the cortical parenchyma.

Ultrastructurally, only protozoal tachyzoites were recognized. They were globular to oval and contained a conoid, micronemes, rhoptries, mitochondria, a nucleus, and dense granules (Figs. 3, 4). In some organisms, the conoidal end was protruding like a nipple (Fig. 4A). Micronemes were few, scattered, and located anterior to the nucleus. The rhoptries were short, had electron-dense contents, and were located anterior to the nucleus. An unusual feature of the rhoptries was that their bulbous end was bent at right angles to the narrower neck portion (Figs. 3 , 4A). Such a shape has not been previously reported for any apicomplexan. Organisms were seen to divide by endodyogeny (Fig. 4B).

None of the antibodies used in the immunohistochemical stains yielded a positive reaction for the organisms. Serology for $T$. gondii, $N$. caninum, and $S$. neurona failed to detect significant levels of antibodies against these organisms in the seal's serum. No PCR amplification product was detected for the samples of cortex; the spiked positive control produced an amplicon of the expected length (193 bases), indicating that inhibitors were not present in the DNA extract.

As previously noted, seals have been found to be susceptible to infection by $T$. gondii and $S$. neurona, both of which can cause a necrotizing meningoencephalitis. In the present case, the negative serology

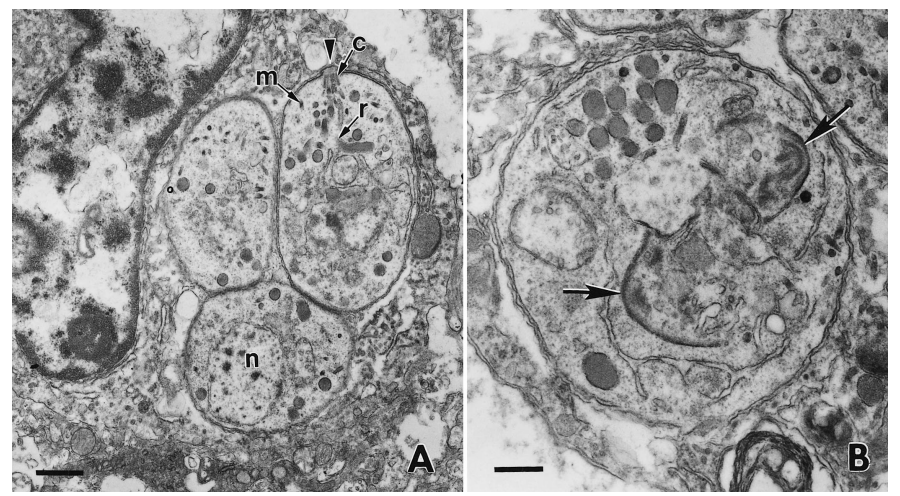

FIGURE 4. Transmission electron micrograph of zoites. (A) Group of 3 zoites: note a protruded (arrowhead) conoid (c), few micronemes $(\mathrm{m})$, and a rhoptry (r) bent at a right angle. (B) Division by endodyogeny, with formation of the conoidal ends of 2 daughter zoites (arrows). Bar in $\mathbf{A}=1 \mu \mathrm{m}$, bar in $\mathbf{B}=600 \mathrm{~nm}$.

and immunohistochemical results and the absence of PCR amplification using $T$. gondii-specific primers, indicate that this organism is different, antigenically and genetically, from the protozoans known to cause neural infections in mammals. Furthermore, the ultrastructural appearance of the organisms had significant differences from that of S. neurona; rhoptries are absent in Sarcocystis spp. merozoites, and they are electron-lucent in $T$. gondii tachyzoites. These findings indicate that this organism is a novel apicomplexan protozoan.

The thymic mass was of an unusual type, most closely resembling the lesion described as multilocular thymic cyst in humans (Suster and Rosai, 1991). This lesion is thought to be a secondary proliferative response to thymic inflammation; the presence of numerous organisms within the mass suggests that this response may have followed thymic infection by the protozoan. Protozoans were also observed within the inflamed bladder mucosa. The presence of both cystitis and renal pyelitis suggest an ascending infection of the urinary tract, either by the protozoan or by a concurrent bacterial infection.

The life cycle and definitive host for this parasite are unknown. Because of the relatively high density of the human population along the California coast and the presence of several marine mammal centers performing necropsies, marine mammals of this region are extensively monitored for diseases. Whereas many other viral, bacterial, and protozoan agents have been described and are regularly observed in these animals, the atypical protozoan described here has not, to our knowledge, been recorded before or since our study. It is, therefore, possible that this harbor seal was an aberrant host for the protozoan, which may not have great significance as a cause of natural mortality for juvenile or adult seals. The multifocal infiltration of macrophages and lymphocytes in the adrenals suggests an earlier episode of herpesvirus infection, which is relatively common in Pacific harbor seals and causes adrenocortical necrosis (Gulland et al., 1997). The inclusion bodies typically found in acute herpesviral infections were not observed, but this may have been because the lesion was at a chronic stage. Herpesvirus infection may have caused immunosuppression and predisposed the pup to infection with a normally nonpathogenic protozoan. Another possibility suggested by the pup's young age is that protozoan infection occurred in utero and that this organism is commonly associated with abortions and reproductive failure, which are difficult to study in feral seal populations.

A histologic section of brain has been deposited in the U.S. National Parasite Collection, Beltsville, Maryland, as USNPC No. 92660. The authors wish to thank Diane Naydan, Mike Manzer, Robert Nordhausen, and John Trupkiewicz for their help on this case.

\section{LITERATURE CITED}

Burg, J. L., C. M. Grover, P. Pouletty, and J. C. Boothroyd. 1989. Direct and sensitive detection of a pathogenic protozoan, Toxoplasma gondii, by polymerase chain reaction. Journal of Clinical Microbiology 27: 1787-1792. 
Dubey, J. P., AND G. Desmonts. 1987. Serological responses of equids fed Toxoplasma gondii oocysts. Equine Veterinary Journal 19: 337-339.

, M. M. Garner, M. D. Stetter, A. E. Marsh, and B. C. Barr. 2001. Acute Sarcocystis falcatula-like infection in a Carmine Beeeater (Merops nubicus) and immuno-histochemical cross-reactivity between Sarcocystis falcatula and Sarcocystis neurona. Journal of Parasitology 87: 824-832.

Gulland, F. M. D., L. J. Lowenstine, J. M. Lapointe, T. Spraker, AND D. P. KING. 1997. Herpesvirus infection in stranded Pacific harbor seals of coastal California. Journal of Wildlife Diseases 33: 450458.

Holshuh, H. J., A. E. Sherrod, C. R. TAylor, B. F. Andrews, and E. B. HowARD. 1985. Toxoplasmosis in a feral northern fur seal. Journal of the American Veterinary Medical Association 187: 12291230.

Lapointe, J.-M., P. J. Duignan, A. E. Marsh, F. M. Gulland, B. C. Barr, D. K. Naydan, D. P. King, C. A. Farman, K. A. Burek Huntingdon, AND L. J. Lowenstine. 1998. Meningoencephalitis due to a Sarcocystis neurona-like protozoan in Pacific Harbor seals (Phoca vitulina richardsi). Journal of Parasitology 84: 1184-1189.
Lindsay, D. S., N. J. Thomas, A. C. Rosypal, and J. P. Dubey. 2001. Dual Sarcocystis neurona and Toxoplasma gondii infection in a Northern sea otter from Washington state, USA. Veterinary Parasitology 97: 319-327.

Miller, M. A., K. W. Sverlow, P. R. Crosbie, B. C. Barr, L. J. Lowenstine, F. M. Gulland, A. E. Packham, And P. A. ConRad. 2001. Isolation and characterization of two parasitic protozoa from a $\mathrm{Pa}-$ cific harbor seal (Phoca vitulina richardsii) with meningoencephalomyelitis. Journal of Parasitology 87: 816-822.

Packham, A. E., K. W. Sverlow, P. A. Conrad, E. F. Loomis, J. D. Rowe, M. L. Anderson, A. E. Marsh, C. Cray, and B. C. Barr. 1998. A modified agglutination test for Neospora caninum: Development, optimization, and comparison to the indirect fluorescentantibody test and enzyme-linked immunosorbent assay. Clinical and Diagnostic Laboratory Immunology 5: 467-473.

Suster, S., AND J. RosaI. 1991. Multilocular thymic cyst: An acquired reactive process. American Journal of Surgical Pathology 15: 388398.

Van Pelt, R. W., And R. A. Dietrich. 1973. Staphylococcal infection and toxoplasmosis in a young harbor seal. Journal of Wildlife Diseases 9: 258-261.

\section{A Gastropod Scavenger Serving as Paratenic Host for Larval Helminth Communities in Shore Crabs}

A. D. M. Latham ${ }^{\star}$, B. L. Fredensborg, L. H. McFarland, and R. Poulin†, Department of Zoology, University of Otago, P.O. Box 56, Dunedin, New Zealand; *Department of Biological Sciences, University of Alberta, Edmonton, Alberta, Canada T6G 2E9; †To whom correspondence should be addressed. e-mail: robert.poulin@stonebow.otago.ac.nz

ABSTRACT: The whelk Cominella glandiformis is an important predator-scavenger of New Zealand intertidal ecosystems; a few whelks can quickly eat all the soft tissues of recently dead crabs. In this study, we demonstrate that whelks can also ingest and act as paratenic hosts for at least 4 helminth species that use crabs as intermediate hosts: metacercariae of the trematode Maritrema sp. and of another unidentified trematode, larval acuariid nematodes, and cystacanths of the acanthocephalans Profilicollis spp. Large whelks ingest disproportionately more helminth larvae than small whelks, but the survival of parasites during their short stay in the whelks is not affected by whelk size. The majority of metacercariae and nematodes are passed out in whelk feces within 3 days of ingestion, whereas the few cystacanths found did not leave whelks until after that time; no parasite was left in whelks 5 days postingestion. Survival of all 4 helminth species was generally very high, though it decreased day by day in 2 species. Given that the avian definitive hosts of all 4 helminths also eat whelks, our results indicate that alternative transmission pathways exist and that parasites can take routes through food webs that are too often ignored.

Trophically transmitted larval helminths inside intermediate hosts face the prospect of being ingested by a range of predators or scavengers that are not suitable definitive hosts. Many helminths avoid this fate by manipulating the behavior or coloration of intermediate hosts in ways that specifically enhance capture by suitable predatory definitive hosts (Moore, 2002; Poulin, 2002). Often, though, the 'wrong' predator consumes the intermediate host. This can constitute a transmission deadend, unless this predator also happens to be a prey of the definitive host. In such situations, the wrong predator becomes a paratenic, or transport, host for the parasite. In complex natural food webs, the use of alternate transmission pathways through paratenic hosts probably occurs much more frequently than what is recorded in the literature.

For instance, McCarthy et al. (1999) documented that metacercariae of the trematode Maritrema arenaria survive passage through the predatory snail Nucella lapillus, which feeds on the barnacles serving as second intermediate hosts of the trematode. Because the bird definitive hosts of the parasite feed on the snails as well as barnacles, the trematode can use $N$. lapillus as paratenic hosts. In this study, we investigate the potential role of another predatory snail, the whelk Cominella glandiformis (Buccinidae), as paratenic host for a diverse group of larval helminths using shore crabs as intermediate hosts. Cominella glandiformis is a common inhabitant of sheltered intertidal mudflats in New Zealand, where it preys on a wide range of invertebrates (Morton and Miller, 1973). Cockles are among its victims, and C. glandiformis has recently been shown to be a potential paratenic host for metacercariae of the trematode Curtuteria australis (Echinostomatidae), which are encysted in cockles (McFarland et al., 2003). Ironically, C. glandiformis is also the first intermediate host of C. australis (Allison, 1979); its occurrence in the diet of shorebird definitive hosts of $C$. australis (Fordham, 1970; Baker, 1974) allows it to play 2 distinct roles in the life cycle and transmission of this parasite. Whelks are also acting as scavengers in intertidal areas, feeding on recently dead organisms. Dead crabs are among the larger animals on which the whelk C. glandiformis feeds, and given the many larval helminths using shore crabs as intermediate hosts in New Zealand, it is likely that whelks act as paratenic hosts for these helminths as well.

The crabs Macrophthalmus hirtipes (Ocypodidae) and Hemigrapsus crenulatus and $H$. edwardsi (Grapsidae) are intermediate hosts of the acanthocephalans Profilicollis spp. (Polymorphidae), the trematode Maritrema sp. (Microphallidae), another unidentified trematode that is possibly a microphallid as well, and larval nematodes (Acuariidae). All these helminths complete their life cycles when ingested by shorebirds such as gulls or oystercatchers. Whelks feed on recently dead crabs, and because they are occasional prey of these same birds (Fordham, 1970; Baker, 1974), they may extend the functional lifespan of all 4 larval parasites beyond the death of the intermediate crab host. Indeed, this study was motivated by the finding of Profilicollis spp. cystacanths and Maritrema sp. metacercariae in field-collected whelks. The objectives of this study were to determine whether the whelk $C$. glandiformis can act as a paratenic host for the 4 larval helminths of New Zealand shore crabs and to quantify the effect of whelk size and passage time inside the whelk on the survival of the parasites. 
Eighty whelks were collected at low tide (mean low water level) from an area of approximately $50 \times 50 \mathrm{~m}$ at Waipuna Bay, Otago Harbour, South Island, New Zealand (45 $\left.47^{\prime} \mathrm{S}, 170^{\circ} 42^{\prime} \mathrm{E}\right)$, on 23 September 2002. Whelks were divided into 4 groups (each $\mathrm{n}=20$ ) of different size classes (shell height $<14 \mathrm{~mm}, 14-17 \mathrm{~mm}, 18-21 \mathrm{~mm},>21 \mathrm{~mm}$ ). They were then returned to the laboratory, placed in 4 separate aquaria (24 $\times 19 \mathrm{~cm}$ ) containing approximately $10 \mathrm{~cm}$ of seawater, and starved for $72 \mathrm{hr}$. All whelks stopped passing feces after this 72 -hr period.

At the end of the starvation period, the whelks were fed similarly sized (approximately 30-mm carapace width) crabs ( $M$. hirtipes) collected from Waipuna Bay on 26 September 2002. We killed the crabs by pithing their brain (located directly posteriorly between the crab's eyes); freshly killed crabs were necessary because we required viable parasites. The carapace of each crab was lifted slightly to allow the whelks easy access to the body cavity of the crabs. Two crabs were placed in each of the 2 aquaria containing whelks from the 2 smallersize classes, whereas whelks from the 2 larger-size classes were fed 3 crabs. Whelks were allowed to feed on the crabs for $3 \mathrm{hr}$, before being removed from their aquaria and placed in individual petri dishes each containing a small amount of seawater.

Whelk feces were examined every $24 \mathrm{hr}$ (for $120 \mathrm{hr}$ ) under a stereomicroscope for the presence of acanthocephalan cystacanths, trematode metacercariae, or nematode larvae. Once the feces had been examined, they were removed from the petri dishes, the dishes were washed, and clean seawater was added. Whelks were never seen feeding on their feces, and thus egested parasites were not reingested by the whelks between fecal examinations. The viability of metacercariae and nematode larvae was assessed during the examination of whelk feces, i.e., if they were intact and moving they were deemed to be viable. Many metacercariae had excysted in the feces but were still active. To validate our assessment on the viability of cystacanths and encysted metacercariae after their passage through the whelk's digestive system, in vitro excystment was carried out. Cystacanths and a sample of metacercariae were incubated for $1 \mathrm{hr}$ at $40 \mathrm{C}$ in petri dishes containing an excystment solution that mimics the chemical conditions inside a bird's intestine (see Irwin et al., 1984). The solution consisted of $5 \mathrm{ml}$ of bicarbonate saline $(0.8 \% \mathrm{w} / \mathrm{v}$ sodium chloride and $1.5 \% \mathrm{w} / \mathrm{v}$ sodium bicarbonate $)$ containing $0.8 \% \mathrm{w} / \mathrm{v}$ sodium taurocholate, $0.3 \% \mathrm{w} / \mathrm{v}$ trypsin, and $5 \mathrm{ml}$ $0.02 \mathrm{M}$ hydrochloric acid containing $0.8 \% \mathrm{w} / \mathrm{v}$ L cysteine (Irwin et al., 1984). After incubation, parasite larvae were examined under a stereomicroscope; because they excysted and were viable, our assessment based on movement was validated. At the close of the final fecal examination (120 hr), all whelks were dissected to see whether any crab parasites had remained in the whelk's digestive system.

Our results show that larvae of all 4 helminths survive passage in whelks. Mean numbers of trematode metacercariae and nematode larvae egested by whelks during the experiment varied significantly among the whelk size classes (Kruskal-Wallis test, all $P<0.0001$ ). As a rule, more parasites passed out of larger whelks (Fig. 1). The differences are too pronounced to be the mere outcome of the fact that we fed 1 extra crab to the 2 largest size classes. There was no difference among whelk size classes, however, with respect to the percentage of metacercariae or nematodes that were viable (Kruskal-Wallis test, all $P>0.25$ ). The patterns also apply to the acanthocephalan Profilicollis spp., although only 5 whelks passed out cystacanths, all of them viable: 1 of the whelks was in the 18 - to $21-\mathrm{mm}$ size class, whereas the other 4 were $>21 \mathrm{~mm}$.

In total, 133 Maritrema metacercariae, 1,200 metacercariae of the unidentified trematode, and 115 larval acuariid nematodes were recovered. Of all trematode metacercariae and nematode larvae passed out by whelks, the greatest proportions were recovered $48 \mathrm{hr}$ after ingestion, followed by $72 \mathrm{hr}$ postingestion; very few were recovered after that (Fig. 2). Although only 7 Profilicollis cystacanths were recovered, none came out of whelks before $72 \mathrm{hr}$ postingestion (Fig. 2). At the end of the experiment, no parasite was found during the dissection of the whelks.

The survival of Maritrema sp. metacercariae appeared unaffected by passage time through the whelk (Fig. 2). In contrast, the survival of both the other trematode and the larval nematodes tended to decrease with time in the whelks, suggesting that the extra transmission time they achieve by using whelks as paratenic hosts is more limited than that for Maritrema sp. metacercariae. In addition, a negative relationship was found between the total number of larval nematodes passing out
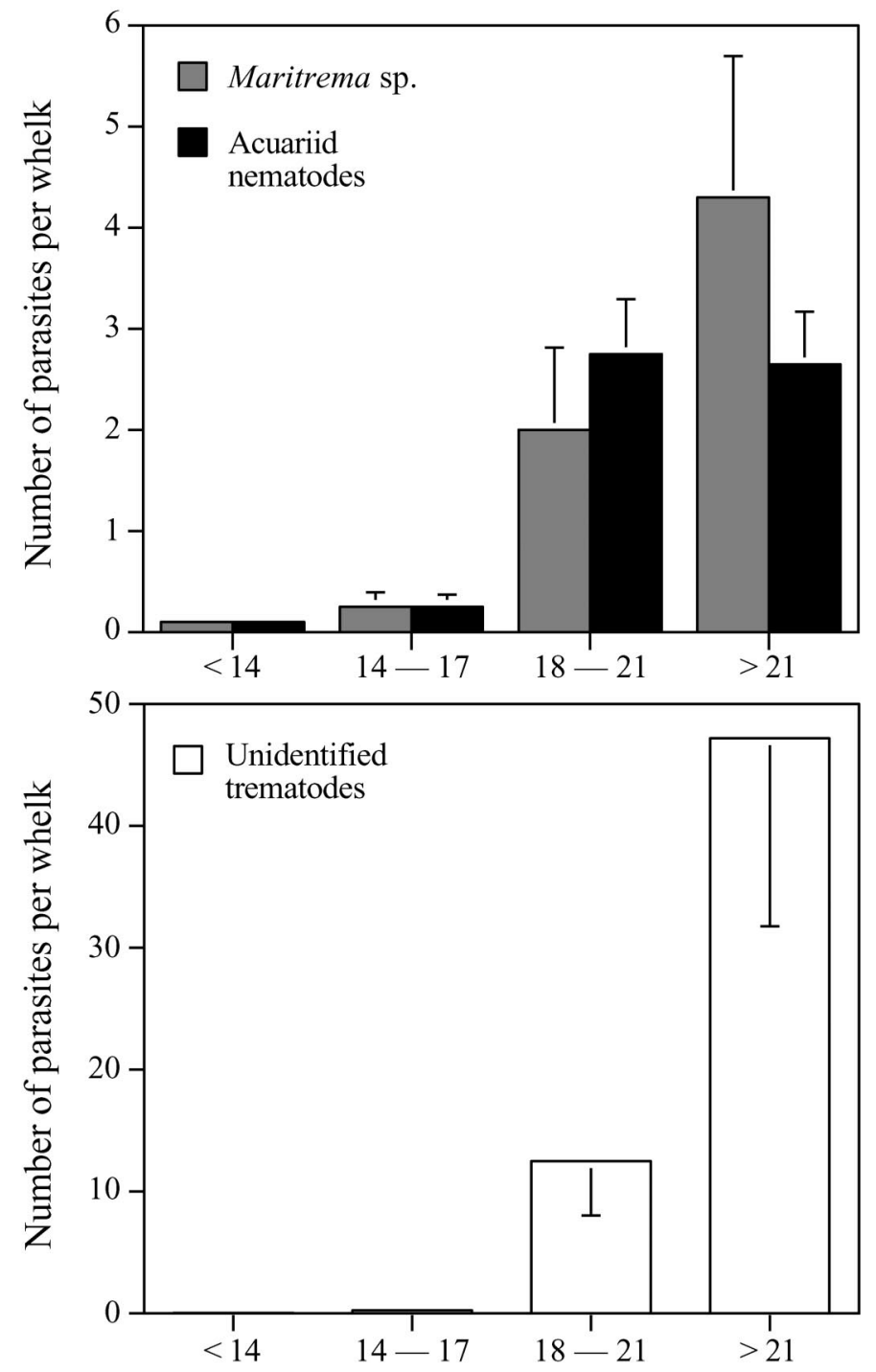

\section{Whelk size class (mm)}

FIGURE 1. Mean $( \pm \mathrm{SE})$ number of parasites passed out by whelks, Cominella glandiformis, of different sizes during the experiment. Data are presented separately for 3 parasite species and include whelks that did not egest any parasites ( $\mathrm{n}=20$ whelks in each size class).

of a whelk and the percentage that were alive (Spearman rank correlation: $r_{\mathrm{s}}=-0.362, \mathrm{n}=40$ snails that passed out nematodes; $P=$ 0.0236). This density-dependent mortality suggests that ingestion of large numbers of nematodes by a whelk may be associated with greater likelihood of damage to these nematodes. Indeed, most dead nematodes recovered in whelk feces had visibly damaged cuticle, possibly as a result of the whelk's mode of feeding. No such relationship was observed for the 2 trematode species (both $P>0.60$ ), whereas all acanthocephalans recovered were viable.

Preliminary observations indicated that all larval helminths found in crabs are viable; it is clear that if any of them die in a crab, they do not persist for very long. Therefore, we can assume that all larval helminths ingested by whelks in this study were viable. It is not clear whether the metacercariae that excysted inside whelks would still be infective to birds should the latter feed on whelks. Even if they were not, our experiment demonstrates that a substantial proportion of larval helminths survive passage through whelks.

Our results also show that considerable numbers of larval helminths 

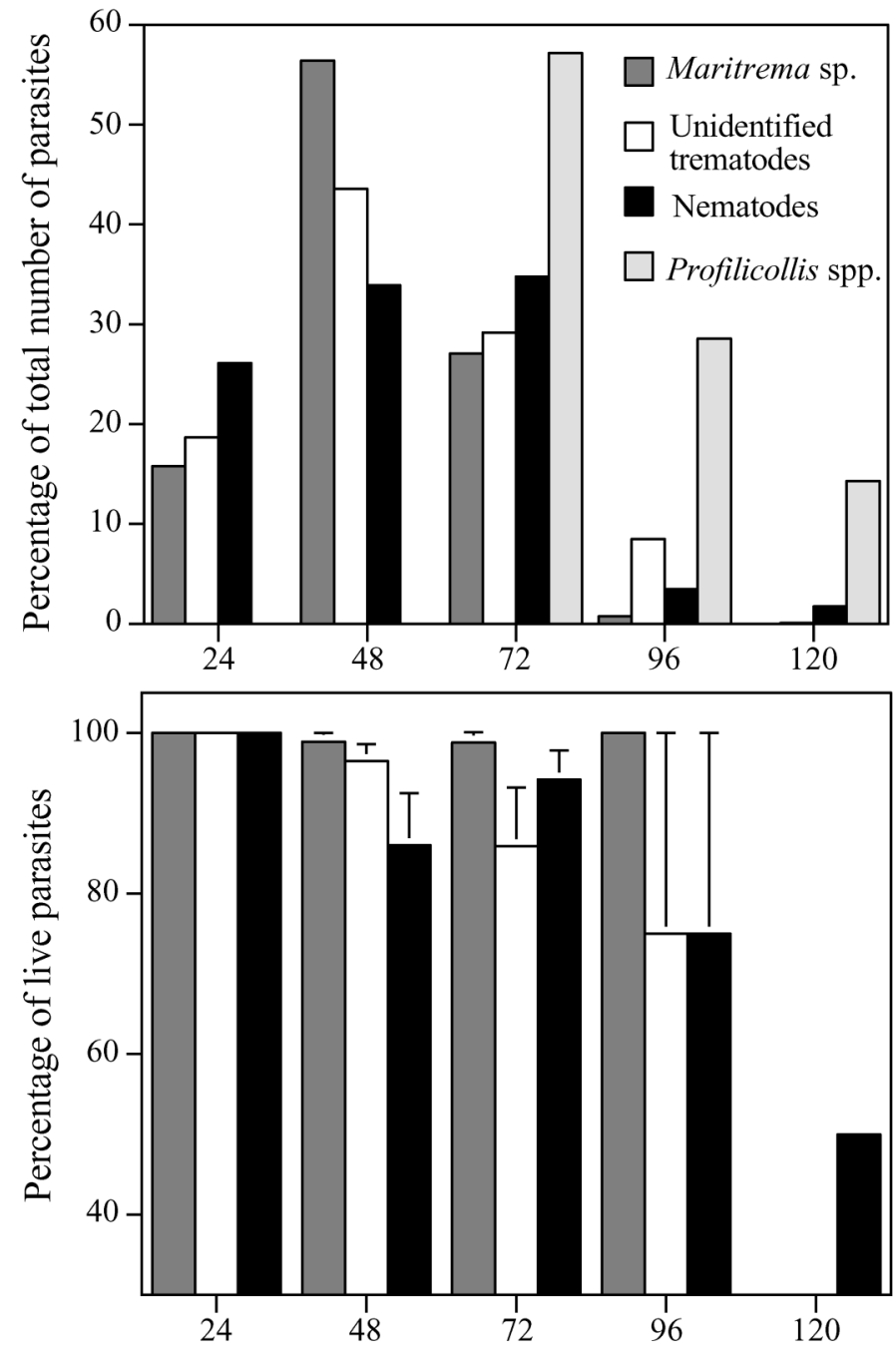

Time post-ingestion (hr)

Figure 2. Percentage of the total number of parasites passed out by whelks, Cominella glandiformis, at different times after ingestion (top), and mean percentage $( \pm \mathrm{SE})$ of live parasites passing out of whelks as a function of time postingestion (data on Profilicollis spp. not shown). Data include only whelks that egested parasites: $\mathrm{n}=26$ for Maritrema sp., $\mathrm{n}=37$ for the unidentified trematode, $\mathrm{n}=40$ for acuariid nematodes, and $\mathrm{n}=5$ for Profilicollis spp.

can be ingested by whelks feeding on dead crabs and that these helminths can survive up to 5 days inside the whelks. To our knowledge, this is the first report on predator-scavenger snails acting as paratenic hosts for larval nematodes or acanthocephalans. Given the large size (approximately $1.5 \times 1 \mathrm{~mm}$ ) of Profilicollis cystacanths, it is remarkable that they can be ingested intact by $C$. glandiformis. Only a fraction of the acanthocephalans present in the crabs was ingested by whelks; large numbers were found scattered over the remains of the crabs after the whelks had finished feeding. Their ingestion appears possible only by the largest whelks, most likely because of size constraints. Acanthocephalans also tended to take longer to be passed out of whelks; it is possible that their size causes them to remain temporarily lodged inside the whelk's digestive tract.

This study and that of McFarland et al. (2003) show that whelks extend the transmission window of at least 5 helminth species for a few days beyond the death of their intermediate hosts. This list should prob- ably also include a sixth species, Ascarophis sp. (Nematoda: Cystidicolidae), a parasite of the same crabs in adjacent areas (Moravec et al., 2003). This nematode is a fish parasite, and several fish species are known to regularly prey on the crabs (McLay, 1988), some of which may also feed on whelks. Given that whelks also feed on many other invertebrates that may serve as intermediate hosts to other helminths, they may harbor a rich community of temporary residents in their gut. Shorebirds regularly feed on whelks and other gastropods (Fordham, 1970; Baker, 1974), and thus these whelk passengers still have a chance of completing their life cycles. For certain invertebrates, the probability of predation or scavenging by whelks is relatively high (e.g., cockles; Ansell, 2001). Our own field observations suggest that every dead crab is within minutes the focus of a group of feeding whelks; often this involves a gull abandoning a partially eaten crab. After the death of the intermediate host, there is thus a second-chance possibility of transmission for all crab parasites if they have not been initially ingested by bird definitive hosts.

The finding of cystacanths and metacercariae in field-collected whelks that inspired the present study gives an indication of the importance of the phenomenon in nature. Of the 62 whelks dissected (also originating from Waipuna Bay), 2 harbored Profilicollis spp. cystacanths and 5 harbored between 3 and 7 Maritrema sp. metacercariae. From these data, it appears that only a small proportion of the total parasite populations is passing through whelks at any one time. For survival in a whelk to increase the parasites' transmission success, they would need to adapt to this second-chance transmission, by increasing their residence time in whelks, for instance. Whether or not this is the case, our results illustrate the existence of alternative routes of transmission for many helminths, and they emphasize the need to consider parasite life cycles in the context of complex food webs and not merely as part of simple predator-prey systems.

We thank Jane Duthie for technical assistance. This research was partially supported by a grant from the Marsden Fund.

\section{LITERATURE CITED}

Allison, F. R. 1979. Life cycle of Curtuteria australis n. sp. (Digenea: Echinostomatidae: Himasthlinae), intestinal parasite of the South Island pied oystercatcher. New Zealand Journal of Zoology 6: 1320.

Ansell, A. D. 2001. Dynamics of aggregations of a gastropod predator/ scavenger on a New Zealand harbour beach. Journal of Molluscan Studies 67: 329-341.

BAKer, A. J. 1974. Prey specific feeding methods of New Zealand oystercatchers. Notornis 21: 219-233.

FordHAM, R. A. 1970. Mortality and population change of dominican gulls in Wellington, New Zealand. Journal of Animal Ecology 39: 13-27.

Irwin, S. W. B., G. McKerr, B. C. Judge, and I. Moran. 1984. Studies on metacercarial excystment in Himasthla leptosoma (Trematoda: Echinostomatidae) and newly emerged metacercariae. International Journal for Parasitology 14: 415-421.

McCarthy, H. O., S. W. B. Irwin, And S. M. FitZPatrick. 1999. Nucella lapillus as a paratenic host for Maritrema arenaria. Journal of Helminthology 73: 281-282.

McFarland, L. H., K. N. Mouritsen, and R. Poulin. 2003. From first to second and back to first intermediate host: The complex transmission routes of Curtuteria australis (Digenea: Echinostomatidae). Journal of Parasitology 89: 625-628.

MCLAY, C. L. 1988. Crabs of New Zealand. Leigh Marine Laboratory Bulletin, University of Auckland, Auckland, New Zealand, 463 p.

Moore, J. 2002. Parasites and the behavior of animals. Oxford University Press, Oxford, U.K., 315 p.

Moravec, F., B. L. Fredensborg, A. D. M. Latham, and R. Poulin. 2003. Larval Spirurida (Nematoda) from the crab Macrophthalmus hirtipes in New Zealand. Folia Parasitologica [In press.]

Morton, J., AND M. Miller. 1973. The New Zealand sea shore, 2nd ed. Collins, London, U.K., 653 p.

Poulin, R. 2002. Parasite manipulation of host behaviour. In The behavioural ecology of parasites, E. E. Lewis, J. F. Campbell, and M. V. K. Sukhdeo (eds.). CAB International, Wallingford, U.K., p. 243-257. 